\title{
Urotensin II in the Pathogenesis of Atherosclerosis in Cholesterol Fed Rats
}

\author{
Nahid M. Tahoon *, Doaa H. Zineldeen ** and Karima El-Desuky *** \\ Departments of Physiology*, Biochemistry**and Pathology*** \\ Faculty of Medicine-Tanta University
}

\begin{abstract}
Background: Atherosclerosis is the most common cause of ischemic heart diseases. Urotensin II is the most potent vasoactive peptide discovered to date with potency that overcomes that of angiotensin II, endothelin-1, serotonin and thromboxan A2. Aim: This study was undertaken to evaluate the role of exogenous urotensin II in the pathogenesis of atherosclerosis and the effect of blocking the endogenous urotensin II. Material and Methods: 32 male wistar rat were divided into 2 groups, normal control group (8 rats) and cholesterol rich diet group (24 rats).The latter is furtherly subdivided into vehicle, urotensin II and palosuran groups (each is 8 rats). In all these groups lipid profile, some inflammatory and atherosclerotic markers were measured. Histopathological examination of tissue samples from aorta and coronaries for atheromatous changes was also done in all groups. Results: Urotensin II produced significant hyperlipidemia, increased CRP and SVACM-1 and decreased NO. Foam cells and VSMC proliferation were evident histopathological findings. The effect of urotensin II was partially reversed by palosuran. Conclusion: urotensin II is an important mediator in the pathogenesis of atherosclerosis in hypercholesterolemic model. Urotensin receptor blocker may be considered as an important therapeutic target in atherosclerosis.
\end{abstract}

\section{INTRODUCTION}

Atherosclerosis, the primary cause of ischemic cardiomyopathy and ultimately a major contributing factor to death, is strongly correlated with hypertension, hyperlipidemia and type II diabetes mellitus. Urotensin II (UII) is the most potent vasoactive peptide identified to date with a potency that overcomes other vasoactive agents like endothelin-1 (ET-1), angiotensin II, serotonin and thromboxane $\mathrm{A} 2^{(\mathbf{1})}$. UII is cyclic peptide of 11 amino acids sharing structural similarity to somatostatin and binds to a class of G-protein coupled receptor known as GPR14 or recently named urotensin receptor $(\mathrm{UT})^{(\mathbf{2})}$. UII/UT complex has been found to be elevated in vascular endothelial dysfunction-related diseases such as essential hypertension, atherosclerosis, coronary artery disease and congestive heart failure ${ }^{(3)}$. UII is highly expressed in endothelial cells, monocytes, macrophage-derived foam cells, myointima and vascular smooth muscle cells (VSMCs) of atherosclerotic human coronary artery using immunohistochemistry, in situ hybridization and reverse transcriptase-polymerase chain reaction $(\mathrm{RT}-\mathrm{PCR})^{(\mathbf{4})}$. 
Palosuran (ACT-058362; 1-[2-(4 benzyl-4-hydroxy-pepridin-1-yL)ethyl]-3-(2-methyl-ginolin-4-yl)-urea sulfate salt) is a non peptidic competitive UT receptor antagonist that binds to two populations of UII binding sites. To date, palosuran is the first UT receptor antagonist that has been tested in human ${ }^{(\mathbf{5})}$.

The aim of the present work is to study the role of chronic exogenously administered UII in the pathogenesis of atherosclerosis in high cholesterol fed rats and the effect of blocking endogenously expressed UII by palosuran.

\section{MATERIAL \& METHODS}

This study was carried out on 32 male wistar rats, collected randomly weighing $200 \pm 50 \mathrm{gm}$ body weight. These animals were housed under 12 hours day/night cycle at room temperature. They were classified into 2 groups.

I- Control group (8 rats): Fed standard chow and tap water.

II- Cholesteral rich diet group (24 rats): fed $2 \%$ cholesteral $+3 \%$ coconut oil enriched diet for 8 weeks (Winlals Company for Pharmaceuticals $)^{(6)}$. Then this group was furtherly subdivided into 3 subgroups, each is 8 rats.

- Subgroup IIa (vehicle group): received vehicle (saline $0.9 \%+$ $\mathrm{NH} 4 \mathrm{OH} 0.01 \%$ ) i.v. daily for 4 weeks.

- Subgroup IIb (urotensin II group): received a bolus daily dose of UII ( $3 \mathrm{nmol} / \mathrm{kg} /$ day) i.v. in vehicle for 4 weeks $^{(7)}$ (Sigma Aldrich Co.).

- Subgroup IIc (Palosuran group): received a bolus daily dose of palosuran (10 $\mathrm{mg} / \mathrm{kg} /$ day) i.v. for 4 weeks ${ }^{(5)}$ (Sigma Aldrich Co.)

- At the end of the experiment, all animals were deprived of food over night, sacrified in the morning and blood samples were collected in EDTA-coated tubes and plasma was separated and stored until analysis for:

(1) Lipid profile parameters:

1. Low density lipoproteincholesteral (LDL-C): by method of Fruchart ${ }^{(\mathbf{8})}$.

2. High density lipoproteincholesteral (HDL-C) by method described by Burstein et al., ${ }^{(9)}$.

3. Plasma triglycerides (TG): Using the method of Fossati ${ }^{(10)}$.

4. Plasma total cholesterol (total Ch.): determined by method of Allain et al., ${ }^{(11)}$.

Atherosclerotic $\begin{array}{r}\text { and } \\ \text { which }\end{array}$
inflammatory markers
include:

1. Nitrite/nitrate (marker for NO) by colorimetric technique according to the method of Bartholomew, ${ }^{(12)}$.

2. C-reactive protein (CRP) by Kushner and Sommerville ${ }^{(13)}$.

3. Soluble vascular cell adhesion molecule-1 (SVCAM-1): measured by immunosorbent assay (ELISA) using commercially available kit ${ }^{(14)}$.

(3) Histopathological examination of tissue samples from aorta and coronaries for atheromatous changes by (Hx \& E).

\section{Statistical analysis:}

Data were presented as mean values $\pm \mathrm{SD}$ and analysis of results 
using one way ANOVA. Differences between individual groups were determined with Scheffe test. Results were considered significant at $\mathrm{P}<0.05$ using SPSS computer program version 16.

\section{RESULTS}

Table (1), Fig. (1) show that LDL-C, TG and total cholesterol significantly increased after high cholesterol diet while HDL-C significantly decreased when compared to normal control group ( $\mathrm{P}$ $<0.05)$.

UII group showed significant increase in LDL-C, TG and total cholesterol and significant decrease of HDL-C when compared to either high cholesterol diet or UII groups (P $<0.05$ ).

Palosuran group led to significant decrease of LDL-C, TG and total cholesterol and significant increase in HDL-C when compared to high cholesterol diet rats $(\mathrm{P}<0.05)$.

As shown in table (2), fig. (2) there is significant decrease in NO after high cholesterol diet alone or together with UII $(\mathrm{P}<0.05)$ and significantly increased after palosuran treatment when compared to control or UII groups $(\mathrm{P}<0.05)$.

Concerning CRP, it is significantly increased in high cholesterol fed rats and UII treatment $(\mathrm{P}<0.05)$ but significantly decreased after palosuran treatment $(\mathrm{P}<0.05)$ as shown in table (2), fig. (3).

As regard SVCAM-1, it is significantly increased after high cholesterol diet alone or together with UII treatment $(\mathrm{P}<0.05)$ and significantly decreased after palosuran treatment $(\mathrm{P}<0.05)$ as shown in table (2), fig. (4).

Table (1): Plasma level of lipid profiles among studied groups.

\begin{tabular}{|c|c|c|c|c|c|c|}
\hline & $\begin{array}{l}\text { Control } \\
\text { (No. 8) }\end{array}$ & $\begin{array}{l}\text { Vehicle } \\
\text { (No. 8) }\end{array}$ & $\begin{array}{l}\text { Urotensin II } \\
(\text { No. 8) }\end{array}$ & $\begin{array}{l}\text { Palosuran } \\
\text { (No. 8) }\end{array}$ & $\bar{F}$ & Relation \\
\hline $\begin{array}{l}\text { LDL-C } \\
\mathrm{mg} / \mathrm{dl}\end{array}$ & $98.25 \pm 6.446$ & $177.20 \pm 7.145$ & $197.11 \pm 6.143$ & $129.86+18.300$ & $138.51^{*}$ & $\begin{array}{l}\text { Control } \\
<\text { vehicle } \\
<\text { urotensin II } \\
>\text { palosuran }\end{array}$ \\
\hline $\begin{array}{l}\text { HDL-C } \\
\mathrm{mg} / \mathrm{dl}\end{array}$ & $24.86 \pm 1.35$ & $18.85 \pm 0.805$ & $13.74 \pm 1.13$ & $25.41 \pm 1.67$ & $148.97 *$ & $\begin{array}{l}\text { Control } \\
>\text { vehicle } \\
>\text { urotensin II } \\
<\text { palosuran }\end{array}$ \\
\hline TG mg/dl & $124.05+2.63$ & $160.79 \pm 5.20$ & $189.68+5.76$ & $148.43 \pm 6.09$ & $228.93 *$ & $\begin{array}{l}\text { Control } \\
<\text { vehicle } \\
<\text { urotensin II } \\
>\text { palosuran }\end{array}$ \\
\hline $\begin{array}{l}\text { Total } \mathrm{Ch} \\
\mathrm{mg} / \mathrm{dl}\end{array}$ & $98.14+4.54$ & $160.51+8.13$ & $189.99 \pm 7.04$ & $130 \pm 7.13$ & $267.13^{*}$ & $\begin{array}{l}\text { Control } \\
<\text { vehicle } \\
<\text { urotensin II } \\
>\text { palosuran }\end{array}$ \\
\hline
\end{tabular}

* Significant $\mathbf{P}<0.05$. 


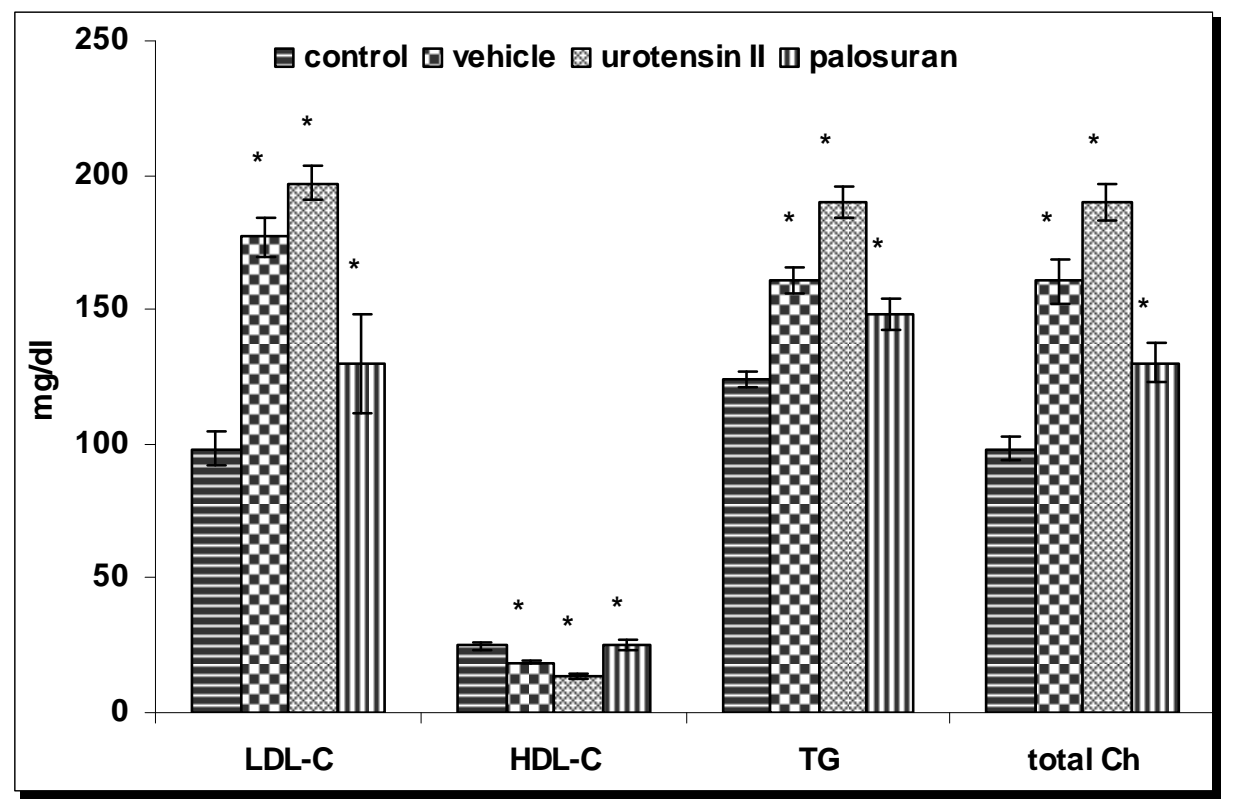

Fig. (1): Plasma level of lipid profile among studied groups.

Table (2): Plasma level of atherosclerotic and inflammatory markers among studied groups.

\begin{tabular}{|c|c|c|c|c|c|c|}
\hline & $\begin{array}{l}\text { Control } \\
\text { (No. 8) }\end{array}$ & $\begin{array}{l}\text { Vehicle } \\
\text { (No. 8) }\end{array}$ & $\begin{array}{l}\text { Urotensin II } \\
\text { (No. 8) }\end{array}$ & $\begin{array}{l}\text { Palosuran } \\
\text { (No. 8) }\end{array}$ & $\bar{F}$ & Relation \\
\hline $\begin{array}{l}\text { Nitrite/nitrate } \\
\mathrm{nmol} / \mathrm{ml}\end{array}$ & $25.14 \pm 1.68$ & $15.10 \pm 1.81$ & $10.10 \pm 1.81$ & $20.73 \pm 1.83$ & $108.13^{*}$ & $\begin{array}{l}\text { Control } \\
>\text { vehicle } \\
>\text { urotensin II } \\
<\text { palosuran }\end{array}$ \\
\hline CRP mg/l & $5.11 \pm 0.51$ & $7.11 \pm 0.51$ & $9.53 \pm 0.58$ & $5.31 \pm 0.62$ & $108.44 *$ & $\begin{array}{l}\text { Control } \\
<\text { vehicle } \\
<\text { urotensin II } \\
>\text { palosuran }\end{array}$ \\
\hline $\begin{array}{l}\text { SVCAM-1 } \\
\mathrm{ng} / \mathrm{ml}\end{array}$ & $25.16 \pm 2.40$ & $33.81 \pm 2.60$ & $47.39 \pm 5.39$ & $30.50 \pm 5.51$ & $39.95 *$ & $\begin{array}{l}\text { Control } \\
<\text { vehicle } \\
<\text { urotensin II } \\
>\text { palosuran }\end{array}$ \\
\hline
\end{tabular}

* Significant $\mathbf{P}<\mathbf{0 . 0 5}$. 


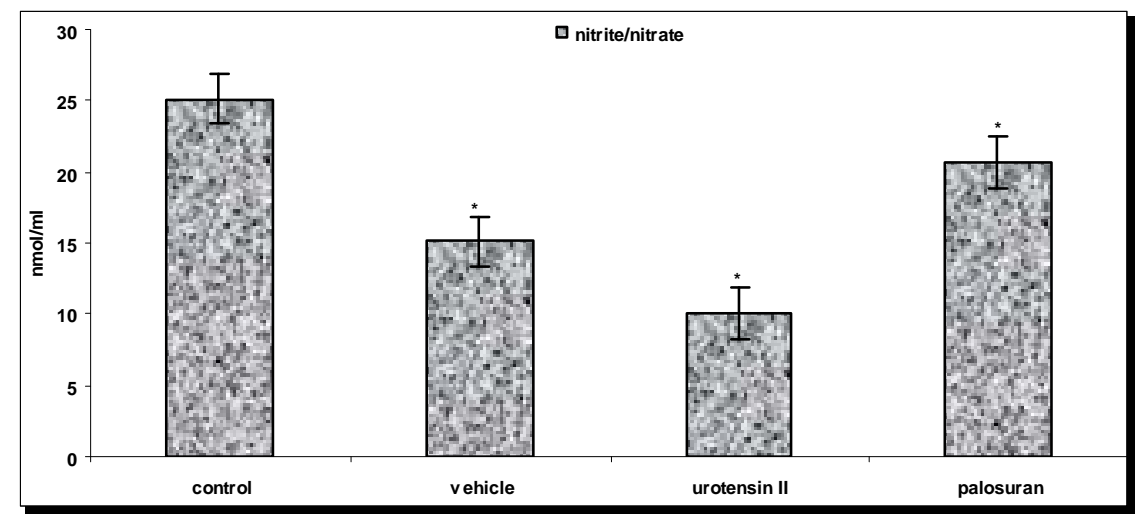

Fig. (2): Plasma level of nitrite/nitrate among studied groups

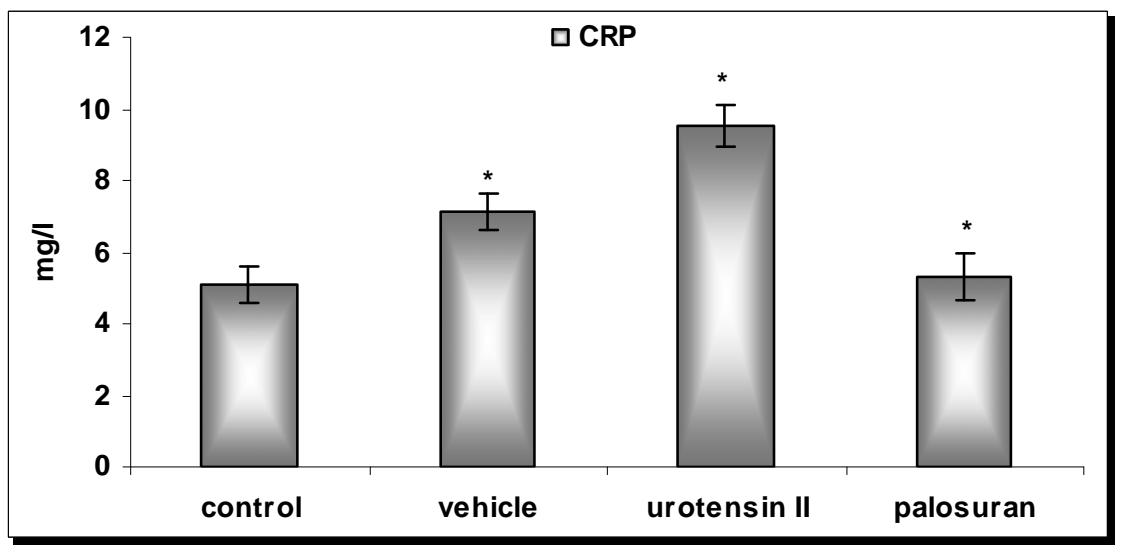

Fig. (3): Plasma level of CRP among studied groups.

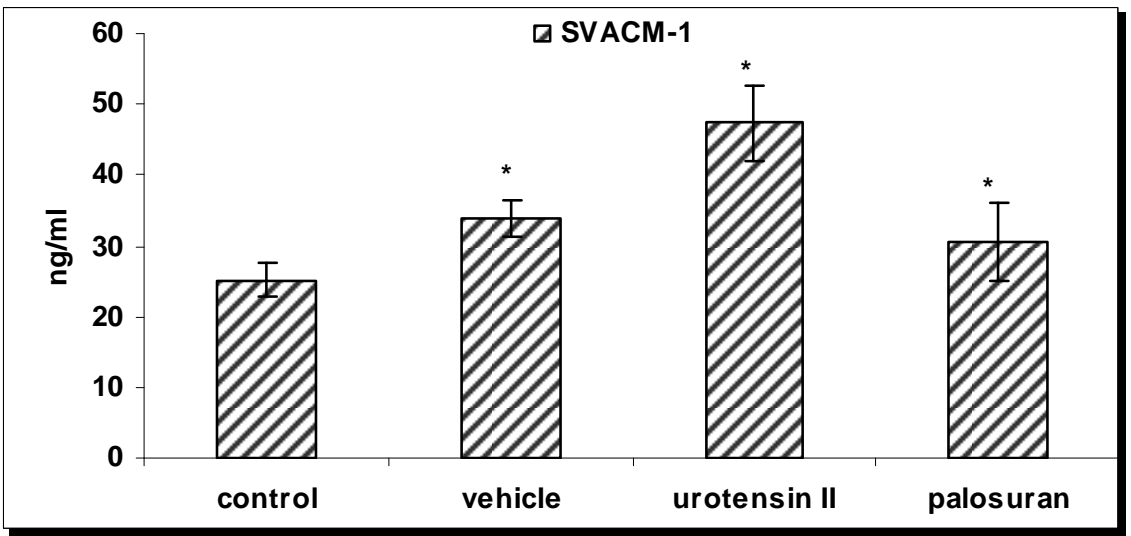

Fig. (4):Plasma level of SVACM-1 among studied groups. 


\section{Histopathological findings:}

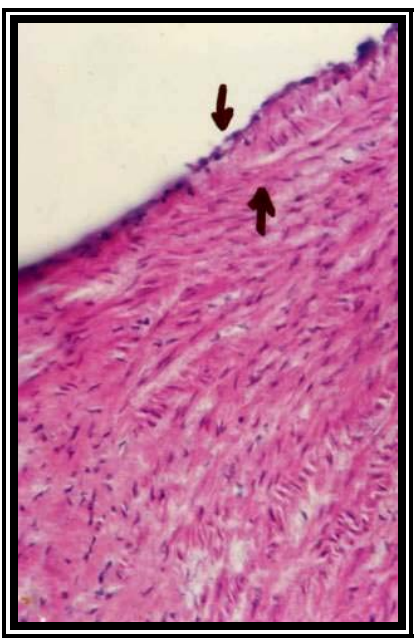

Fig. (5) Photomicrograph of section in aorta of control rat showing normal endothelial lining, normal subendothelial intima and normal musculature (Hx \& E. x 250).

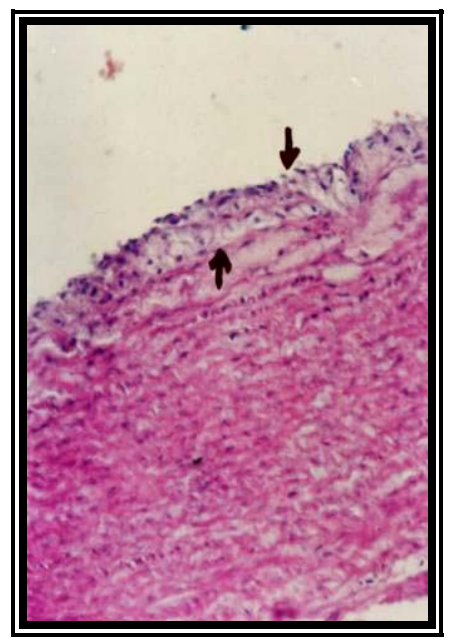

Fig. (6) Photomicrography of section in aorta of hyperlipidemic rat showing destruction of musculo-elastic layer with multiple foci of intimal and subintimal foamy cells ( $\mathrm{Hx} \& \mathrm{E}$. x 250).

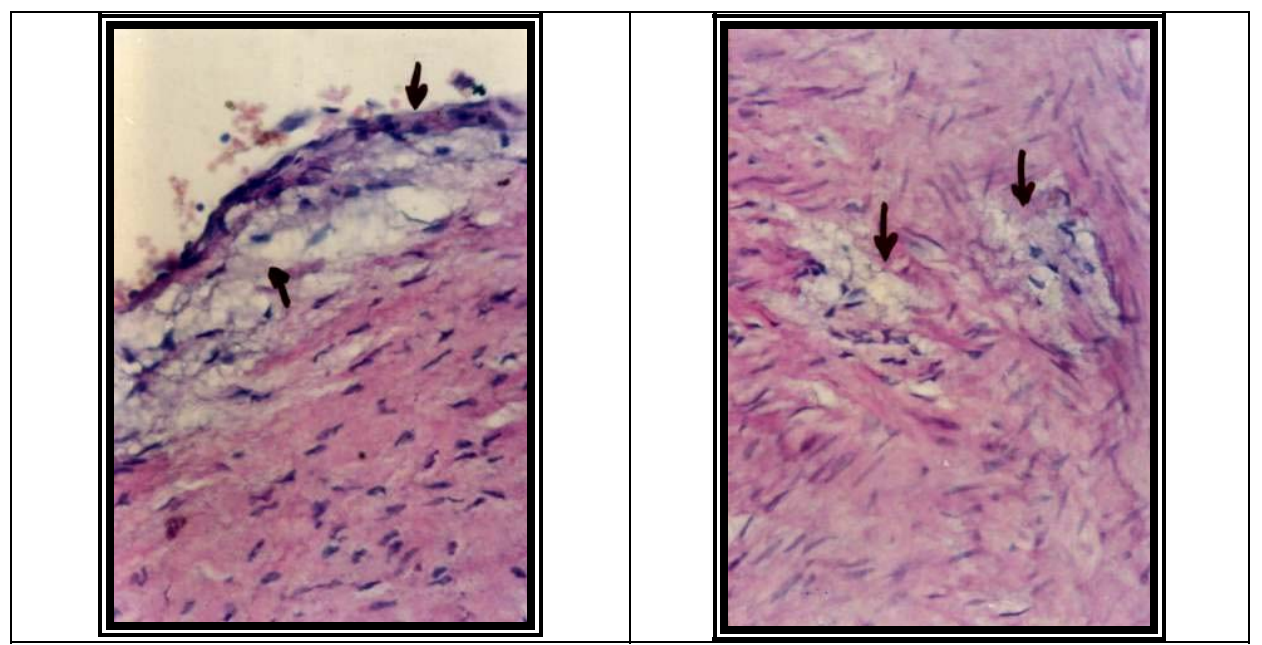

Fig. (7): Photomicrograph of sections from coronaries (A) and aorta (B) of hyperlipidemic rats treated with UII showing: (A) early atheromatous plaque showing patchy endothelial denudation, medial degeneration, with multiple foci of foamy cells (Hx \& E. x 250). (B) deeper sections from the aorta, showing patchy areas of degeneration studed with foamy cells, and proliferating vascular smooth muscle cells (VSMCs) (Hx \& E. x 400). 


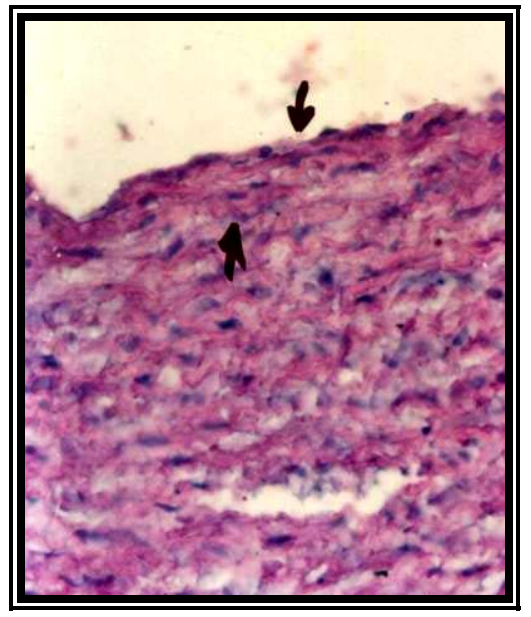

Fig. (8) Photomicrography of section in aorta of hyperlipidemic rat treated with palosuran showing apparently normal histopathological structure (non-denuded endothelium, no visible gross plaques with diffuse minute hyalinization in the intima without foam cell accumulation) (Hx \& E. x 400).

\section{DISCUSSION}

The results of the present study suggest a prominent role of UII in mediating atherosclerosis in high cholesterol fed rats as evidenced from hyperlipidemia (increased LDL-C, TG and total $\mathrm{Ch}$. and decreased HDL-C), inflammatory and atherosclerotic markers (decreased NO, increased CRP and SVCAM-1) and histopathological findings (atheromatous plaques of foam cells and VSMC proliferation).

UII may help induction of hyperlipidemia by enhancing the activity of depot lipase and channel of glucose to free fatty acid synthesis. Hyperinsulinemia and insulin resistance caused by UII may also be a cause of hyperlipidemia ${ }^{(15,16)}$.

Many mechanisms may serve as causal links between hyperlipidemia and many of the major pathways responsible for atherogenic disorders.
UII acts in synergy with mildly oxidized LDL (mox LDL) to promote generation of oxidative stress in vasculature via activation of nicotinamide adenine dinucleatide phosphate (NADPH) oxidase ${ }^{(17)}$. Stimulation of (mox LDL) and reactive oxygen species (ROS) by UII stimulates acyl-coenzyme A: cholesterol acyl transferase-1 (ACAT1) which stimulates estrification and storage of free cholesterol as cholesterol esters in lipid droplets and hence formation of foam cells from monocyte-derived macrophages. UII also increases expression of scavenger receptors $\left(\mathrm{CD}_{36}\right.$ and scavenger receptor class $\mathrm{A})^{(\mathbf{1 8})}$.

Stimulation of monocytes with lipopolysaccharides (LPS) increases UT receptor mRNA and protein expression. There is also evidence that UII acts as chemoattractant for UT receptor-expressing monocytes via activation of Rho $\mathrm{A} / \mathrm{Rho}$ kinase 
signaling cascade and actin cytoskeleton reorganization. At the same time, cloning and functional characterization of the human UT receptor gene promotor revealed the presence of NF-Kappa B-binding sites involved in the stimulation of UT receptor gene expression by $\operatorname{LPS}^{(\mathbf{1 9})}$. UII also stimulates CRP, (VCAM-1) and intercellular adhesion molecule-1 (ICAM-1) expression in human endothelial and VSMCs which act as chemoathractant for UT receptor expressing monocytes ${ }^{(20)}$.

Endothelial dysfunction may be due to impaired nitric oxide (NO) synthesis and/or inactivation of endothelium-derived NO by ROS ${ }^{(21)}$. Endothelial dysfunction complicates hypertension and is the precursor of atherosclerosis. Many studies stated the rise of UII blood levels in patients with essential hypertension and atherosclerosis and explained its pivotal role in induction of VSMC contraction and proliferation ${ }^{(21,22)}$.

The mechanism of UII-induced VSMC contraction may be increased ET-1 expression or through activation of Rho A/Rho kinase pathway and phosphorylation of myocin light chain $(\mathrm{MLC})^{(\mathbf{2 3})}$. Activation of phospholipase-C dependant $\mathrm{IP}_{3}$ leading to increased cytosolic calcium ions and activation of protein kinase $\mathrm{C}$ (PKC)may also involved ${ }^{(24,25)}$.

UII acts in synergy with mox LDL to induce VSMC proliferation through generation of ROS which activate mitogen activated protein kinase and protein kinase $B$ (MAPK/PKP (Akt)), the latter activate plasminogen activatior inhibitor (PAI1) in $\operatorname{VSMC}^{(\mathbf{2 6})}$. Activation of Rho A/Rho kinase pathway also stimulates
DNA synthesis in VSMCs at highest rate among other vasoactive agents assessed by measuring $[3 \mathrm{H}]$ thymidine incorporation into DNA ${ }^{(27)}$. $\mathrm{C}$-Scr tyrosine kinase/PKC/MAPK is another pathway ${ }^{(28)}$. UII stimutes phosphorylation and hence transactivation of epidermal growth factor receptors (EGFR) ${ }^{\mathbf{( 2 9})}$.

UII stimulates proliferation and migratory capacity of endothelial progenitor cells (EPCs) from bone marrow via activation of Rho A/Rho kinase pathway which phosphorylates MLC of EPCs. This is supported by the high expression of UT receptors in the $\operatorname{EPCs}^{(7,30)}$. This provides new insights into role of UII in atherosclerosis not only by inducing collateral formation but also by promoting vasculogenesis and angiogenesis. UII also was found to stimulate vascular endothelial growth factor (VEGF) ${ }^{(3)}$.

In the fact of existing results showing the role of palosuran even without exogenous UII to reduce lipid profile, inflammatory and atherosclerotic markers and also improved the atherosclerotic lesions in histopathological examination. This is another evidence for the role of endogenously expressed UII in the pathogenesis of atherosclerosis. These results are agreed with many other studies $^{(\mathbf{1 8 , 3 1})}$. This may provide a new therapeutic strategy for treatment of atherosclerosis.

\section{CONCLUSION}

UII/UT receptor complex is an important mediator in atherosclerosis by inducing hyperlipidemia, inflammatory and oxidative stress. 
Foam cell formation and VSMC proliferation are important histopathological features. UT receptor blockers may provide a promising therapeutic strategy against atherosclerosis and ischemic heart diseases.

\section{REFERENCES}

1. Watanabe T., Takahashi K., Kanome T., Hongo S., Migazaki A., Koba S., Katgiri T., Bakara R. and Benedict C.R.: Human urotensin II potentiates the mitogenic effect of mox LDL on vascular smooth muscle cells: Comparison with other vasoactive agents and hydrogen peroxide. Hypertens Res. 2006 Oct; 29(10): 821-831.

2. Ross B., Meckendy K. and Giaid A.: Role of urotensin II in health and disease. Am J Physiol Regul Integr Comp Physiol. 2010 May; 298(5): R1156-1172.

3. Guidolin D., albertin G. and Ribathi D.: Urotensin II as an angiogenic factor. Peptides. 2010 Jun; 31(6): 1219-1224.

4. Watanabe T., Kamome T., Miyazaki A., and Katagiri T.: Human Urotensin II as a link between hypertension and coronary artery disease. Hypertens Res. 2006 Jun; 29(6): 375-387.

5. Russell F.D.: Urotensin II in cardiovascular regulation. Vascular Health and Risk Management. 2008; 4(4): 775785 .

6. Csont T., Balongh G., Csonk C., Boros I., Horvath I., vigh L. and Ferdinandy P.:
Hyperlipidemia induced by high cholesterol diet inhibits heat shock response in rat hearts. Biochem Biophys Res Commun. 2002 Feb; 290(5): 1535-1538.

7. Xu S., Jang H., Wu B., Yang J. and Chem S.: Urotensin II induces migration of endothelial progenitor cells via activation of RhoA/Rho kinase pathway. Tohoku JEXP Med. 2009 Dec; 219(4): 283-288.

8. Fruchart J.C.: Separation of low density lipoproteins. Rev Fr Des Laboratories. 1982; 103: 7-17.

9. Burstein M., Scholnick H.R. and Morfin P.: Separation of high density lipoproteins. J Lipid Res. 1970; 19: 583.

10. Fossati P. and Prencipe L.: Serum triglycerides determined colorimetrically with an enzyme that produces hydrogen peroxide. Clin Chem. 1982 Oct; 28(10): 2077-2080.

11. Allain C.C. Poon L.S., Chan C.S., Richmond W. and Fu P.C.: Enzymatic determination of total serum cholesterol. Clin Chem. 1974; 20(4): 470-475.

12. Bartholomew P.: A rapid method for assay of nitrate in urine using the nitrate reductase enzyme of Escherichia Coli. Fd Chem Toxic. 1984; 22: 541.

13. Kushner I. and Somerville J.A.: Estimation of molecular size of C-reactive protein in serum. Biochem Biophys Acta. 1970 Apr; 207(1): 105-114.

14. Liu X., qu D., He F., Lu Q., Wang J. and Cai D.: Effect of lycopene on vascular endothelial function and expression of inflammatory agents in 
hyperhomocysteinemic rats. Asia Pac J Clin Nutr. 2007; 16 Suppl 1: 244-248.

15. Sheridan M.A., Plisetskaya E.M., Bern H.A. and Garboman A.: Effects of somatostatin 25 and urotensin II on lipid and carbohydrate metabolism of Coho Salman Oncorhynchus Kisutch. Gen Comp Endocrinol. 1987 Jun; 66(3): 405-414.

16. Kiss R.S., You Z., Genest J.Jr., Behm D.J. and Giaid A.: Urotensin II differentially regulates macrophages and cholesterol homeostasis. Peptides. 2011;32(5):956-63.

17. Djordjevic T., Belaiba R.S., Bonello S., Pfeilschifter J., Hess J. and Gorlach A.: Human urotensin II is a novel activator of NADPH oxidase in human pulmonary artery smooth muscle cells. Arterioscelr. Thromb Vasc Biol. 2005; 25: 519-525.

18. Shiraishi Y., Watanabe T., Suguro T., Nagashima M., Kato R., Hongo S., Itabe H., Miyazaki A., Hirano T. and Adachi M.: Chronic urotensin II infusion enhances macrophage foam cell formation and atherosclerosis in apolipopratein E-knockout mice. J Hypertens. 2008 Oct; 26(10): 1955-1965.

19. Segain J.P., Rolli-Drkinderen M., Gerviois N., Raingeard de La Blétiére D., Loirand G. and Pacand P.: Urotensin II is a new chemotactic factor for UT receptor-expressing monocytes. J Immunol. 2007 Jul; 179(2): 901909.
20. Watanabe T., Arita S., Shiraishi Y., Suguro T., Sakai T., Hongo S. and Miyazaki A.: Human urotensin II promotes hypertension and atherosclerotic cardiovascular diseases. Curr Med Chem. 2009; 16(5): 550563.

21. Gendron G., gobeil F.J.R., Belanger S., Gongnon S., Regoli D. and D'Orleans-Juste P.: Urotensin II-induced hyotensive responses in Wistar-Kyoto (WKY) and spontaneously hypertensive rats. Peptides. 2005; 26: 1468-1474.

22. Suguro T., Watandbe T., Ban Y., Kodate S., Misaki A., Hirano T., Miyazaki A. and Adachi M.: Increased human urotensin II levels are correlated with carotid atherosclerosis in essential hypertension. American Journal of Hypertension. 2007 Feb; 20: 211-217.

23. Lin Y., Matsumwra K., Tsuchihashi T., Fukuhara M., Fujii K. and Iida M.: Role of ERK and Rho Kinase pathways in central pressor action of urotensin II. J Hypertens. 2004; 22: 983-988.

24. Tasaki K., Hori M., Ozaki H., Karaki H. and Wakabayashi I.: Mechanism of human urotensin II - induced contraction of aorta. J. Pharmacol Sci. 2004; 94: 376383.

25. Behm D.J., Doe C.P., Johns D.G., Maniscalco K., Stankus G.P., Webberley A., Witlette R.N. and Douglas S.A.: Urotensin II: a novel systemic hypertensive factor in the cat. Naunyn Schmiedebergs Arch. 
Pharmacol. 2004; 369: 274-280.

26. Watanab T., Pakala R., Katagiri T. and Benedict C.R.: Synergistic effect of urotensin II with mildly oxidized LDL on DNA synthesis in vascular smooth muscle cells. Circulation. 2001; 104: 16-18.

27. Sauzeau V., Le Mellionnec E., Bertoglio J., Scalbert E., Pacaud P. and Loirond G.: Human urotensin II-induced contraction and arterial smooth muscle cell proliferation are mediated by Rho A and Rho kinase. Circ Res. 2001; 88: 11021194.

28. Watanabe T., Pakala R., Katagiri T. and Benedict C.R.: Synergistic effect of urotensin II with serotonin on vascular smooth muscle cell proliferation. J Hypertens. 2001; 19: 21912196.

29. Tasai C.S., Loh S.H., Liu J.C., Lin J.W., Chen Y.L., Chen
C.H. and Cheng T.H.: Urotensin II-induced endothelin-1 expression and cell proliferation via epidermal growth factor receptor transactivation in rat aortic smooth muscle cells Atherosclerosis. 2009 Sep; 206(1): 86-94.

30. Shi L., Ding W., Li D., Wang Z., Jang H., Shang J. and Tang C.: Proliferation and antiapoptotic effects of human urotensin II on human endothelial cells. Atherosclerosis. 2006 ;188(2):260-4.

31. Maguire J.J., Kur R.E., Wiley K.E., Kleinz M.J. and Davenport A.P.: Cellular distribution of immunreactive urotensin II in human tissue with evidence of increased expression in atherosclerosis and a greater constrictor response of small compared to large coronary arteries. Peptides. 2004; 25: 1767-74. 


\section{اليوروتنسين_r كمتسبب لتصلب الثرايين فى الفئران المغذاة بالكوليسترول}

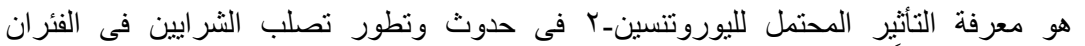 بالكوليسترول و أيضاً معرفة تأثئير العقار المضاد لليور روتنسين الموجود داخل الجسم.

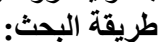 أجرى هذا البحث على بـ من الفئران الذكور قسمت إلى مجمو عتان:

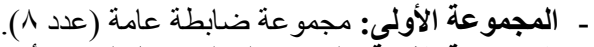

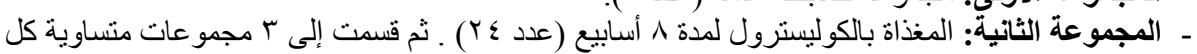

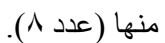 ــ ـ المجموعة الثانية أ: أخذت محلول ملح مع هيدروكسيد الأمونيوم لمدة ع أسابيع.

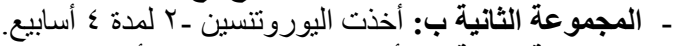

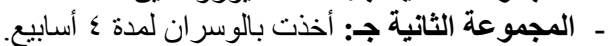

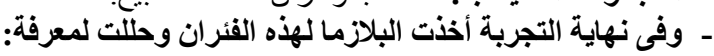 1. نسبة الدهون (دهون ذات كثافة منخفضة و عالية وكوليسترول كلى ودهون ثلاثية).

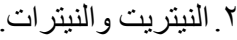

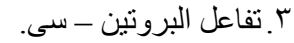

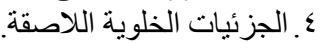 ه. بالإضافة لدر اسة هستوباتولو جية لأنسجة الأورطى و الثريان التاجى لكل المجموعات. والتيأج:

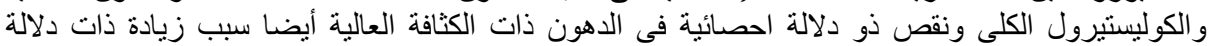

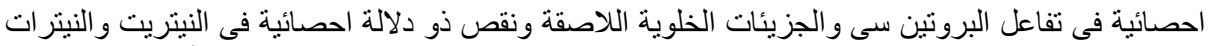

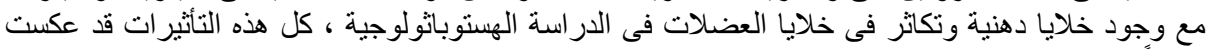

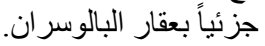

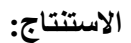

ظالكرت هذه النتائج أن لليوروتنسين_r تأثير فعال فى إحداث وتطور تصلب الثرايين في الفئران المغذاة

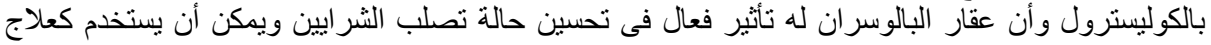
لتصلب الثر ايين فى المستقبل. 